\title{
Enantioselective Organocatalytic Aminomethylation of Aldehydes: A Role for Ionic Interactions and Efficient Access to $\boldsymbol{\beta}^{2}$-Amino Acids
}

\author{
Yonggui Chi, Samuel H. Gellman* \\ Department of Chemistry, University of Wisconsin, Madison, Wisconsin 53706 \\ gellman@chem.wisc.edu
}

Supporting Information

General Procedures. Analytical thin-layer chromatography (TLC) was carried out on Whatman TLC plates precoated with silica gel $60(250 \mu \mathrm{m}$ thickness). Visualization was performed using a UV lamp or potassium permanganate stain. Column chromatography was performed on EM Science silica gel (230-400 mesh).

Materials. (S)-Diphenylmethyl pyrrolidine (B) was purchased from Acros Organics; other commercial reagents were purchased from Sigma-Aldrich. DMF is biotech grade from Sigma-Aldrich. All commercial reagents were used as received. N,O-acetal (A) was prepared using literature procedures. ${ }^{1}$

Instrumentation. Proton nuclear magnetic resonance ( ${ }^{1} \mathrm{H}$ NMR) spectra were recorded on Bruker AC-300 (300 MHz) spectrometers. Chemical shifts were recorded in parts per million (ppm, $\delta$ ) relative to tetramethylsilane $(\delta 0.00)$. ${ }^{1} \mathrm{H}$ NMR splitting patterns are designated as singlet (s), doublet (d), triplet $(\mathrm{t})$, or quartet (q). All first-order splitting patterns were assigned on the basis of the appearance of the multiplet. Splitting patterns that could not be easily interpreted are designated as multiplet $(\mathrm{m})$ or broad (br). Carbon nuclear magnetic resonance $\left({ }^{13} \mathrm{C}\right.$ NMR) spectra were recorded on a Bruker AC-300 (75 $\mathrm{MHz}$ ) spectrometer. Mass spectra (MS) were obtained using an electrospray ionization (ESI) mass spectrometer. Chromatographic enantiomeric excess (ee) determinations were performed on a Shimadzu 10A HPLC using a Chiracel OD or ODH analytical column (detection at $254 \mathrm{~nm}$ ). Optical rotations were measured using a $5 \mathrm{~mL}$ cell with a $1 \mathrm{dm}$ path length on a Perkin-Elmer 241 digital polarimeter and are reported as follows: $[\alpha]_{D}^{\text {rt }}(c$ in g per $100 \mathrm{~mL}$ solvent $)$.

\section{Stereochemistry Determination:}

Absolute configuration of compound S1 was obtained by X-ray diffraction analysis. ${ }^{2}$ Absolute configuration of $\beta$-propyl $\gamma$-dibenzylamino alcohol (S3) was assigned by comparing the optical rotation of S4 and S2. The absolute configuration of other $\beta$-substituted $\gamma$-dibenzylamino alcohols from the Mannich reaction was assigned by analogy to $\mathbf{S 3}$.

\footnotetext{
${ }^{1}$ (a) Hosomi, A.; Iijima, S.; Sakurai, H. Tetrahedron. Lett. 1982, 23, 547. (b) Enders, D., Ward, D.; Adam, J.; Raabe, G. Angew. Chem. Int. Ed. 1996, 35, 981. (c) Rehn, S.; Ofial, A. R.; Mayr, H. Synthesis, 2003, 1790.

${ }^{2} \mathbf{S} 1$ were prepared using similar protocol that was used to prepare $\mathbf{S 3}$. Yonggui Chi, Samuel H. Gellman, manuscript in preparation.
} 
$\overbrace{P r}^{O}+\sum_{P h}^{O M e} \overbrace{(S)}^{I} P h$

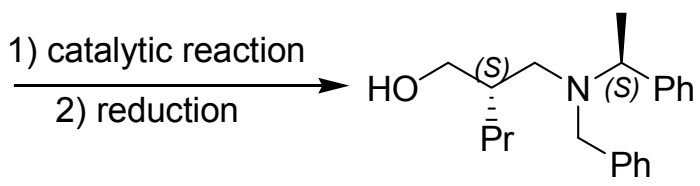

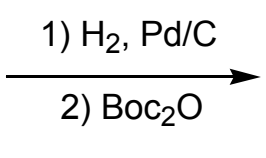

HO $\underset{\substack{(S) \\ \overline{\mathrm{P} r}}}{\mathrm{SHBoc}}$

S1

S2<smiles>CCCC(=O)CC(=O)N(Cc1ccccc1)Cc1ccccc1</smiles>

1) $20 \mathrm{~mol} \% \mathrm{~L}$-proline

$\mathrm{DMF} /-25^{\circ} \mathrm{C} / 24 \mathrm{~h}$

2) excess $\mathrm{NaBH}_{4}$

$\mathrm{MeOH} / 0^{\circ} \mathrm{C} / 20 \mathrm{~min}$<smiles>CC[C@H](CO)CN(Cc1ccccc1)Cc1ccccc1</smiles>

1) $\underset{\mathrm{H}_{2}, \mathrm{Pd} / \mathrm{C}}{\text { 2) } \mathrm{Boc}_{2} \mathrm{O}}$<smiles>CC(C)(C)OC(=O)NC[Si](P)(CO)CO</smiles>

S3 ( $50 \%$ ee)

S4

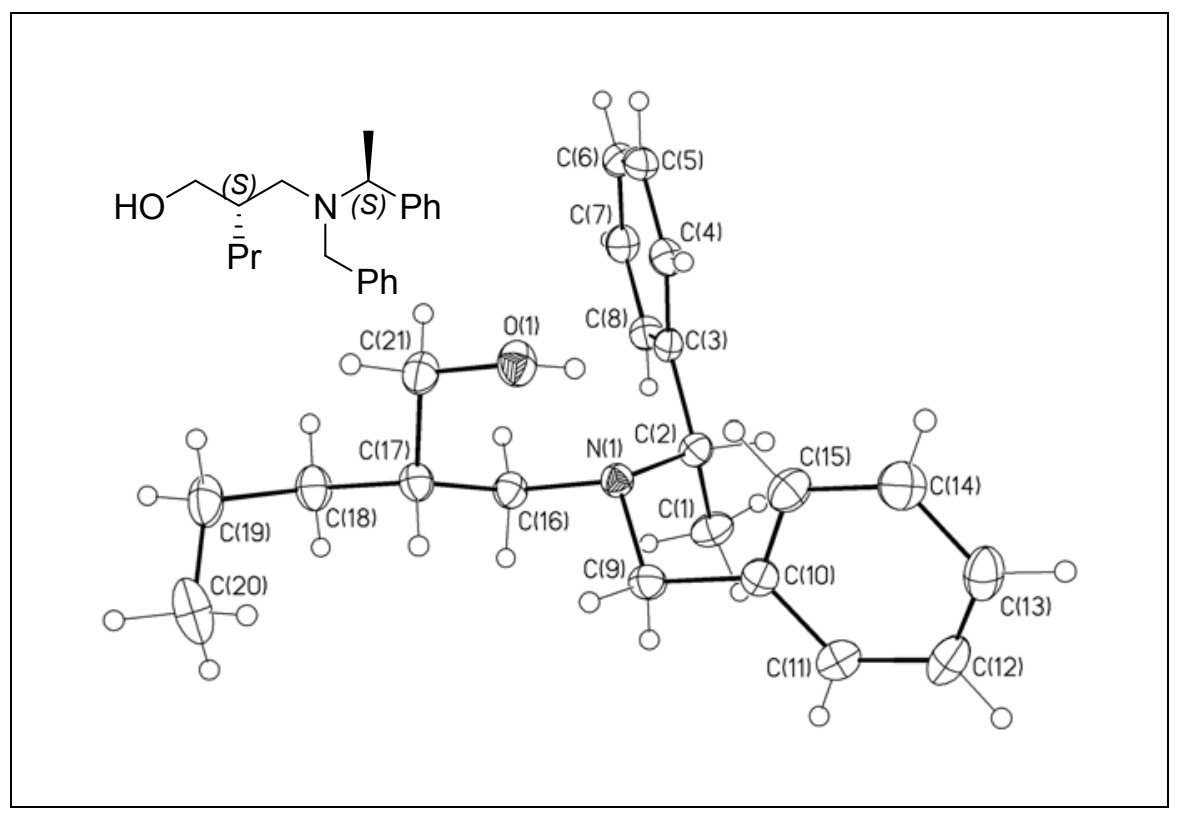

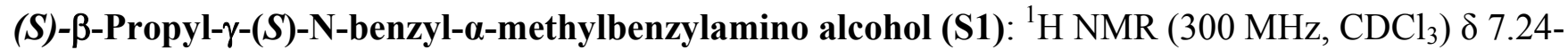
$7.35(\mathrm{~m}, 10 \mathrm{H}), 5.05(\mathrm{br}, 1 \mathrm{H}), 4.03(\mathrm{q}, \mathrm{J}=6.9 \mathrm{~Hz}, 1 \mathrm{H}), 3.92 \& 3.97(\mathrm{~s}, 1 \mathrm{H}), 3.58(\mathrm{~m}, 1 \mathrm{H}), 3.33$ \& 3.38 (s, 1H), 2.94-2.98 (m, 1H), 2.53-2.59 (m, 1H), 2.40-2.48 (m, 1H), 1.89-1.96 (m, 1H), $1.35(\mathrm{~d}, \mathrm{~J}=6.9,3 \mathrm{H})$, 1.21-1.31 (m, 2H), 0.91-0.99 (m, 3H), 0.85 (t, J = 7.5, 3H). ${ }^{13} \mathrm{C}$ NMR (75 MHz, CDCl $)$ : 142.8, 140.0, 129.5, 128.7, 128.4, 128.3, 127.5, 127.3, 68.5, 56.5, 55.2, 54.9, 36.5, 32.5, 20.6, 14.5, 9.5. TOF-MS-ESI: $[\mathrm{M}+\mathrm{H}]^{+}$calculated 312.2 , found 312.4 . X-ray quality crystals were obtained via slow evaporation of a hexane solution.

(S)- $\beta$-Propyl- $\boldsymbol{\gamma}$ - Bocamino alcohol (S2): NMR $\left(300 \mathrm{MHz}, \mathrm{CDCl}_{3}\right) \delta 4.82$ (br, $\left.1 \mathrm{H}\right), 3.48-3.64(\mathrm{~m}, 1 \mathrm{H})$, 3.29-3.44 (m, 3H), 3.04-3.13 (m, 1H), 1.54-1.66 (m, 1H), $1.45(\mathrm{~s}, 9 \mathrm{H}), 1.09-1.41(\mathrm{~m}, 4 \mathrm{H}), 0.91(\mathrm{t}, \mathrm{J}=$ $7.2 \mathrm{~Hz}, 3 \mathrm{H}) .{ }^{13} \mathrm{C} \mathrm{NMR}\left(75 \mathrm{MHz}, \mathrm{CDCl}_{3}\right): 157.7,80.0,62.8,41.5,41.0,31.1,28.6,20.5,14.5$. TOF-MSESI: $[\mathrm{M}+\mathrm{H}]^{+}$calculated 218.2, found 218.4; $[\mathrm{M}+\mathrm{Na}]^{+}$calculated 240.2, found 240.4; $[2 \mathrm{M}+\mathrm{Na}]^{+}$ calculated 457.4, found 457.8. Optical rotation: $[\alpha]^{\mathrm{rt}}=+7.0^{\circ}(c=0.20, \mathrm{MeOH})$.

(S)- $\beta$-Propyl- $\gamma$-dibenzylamino alcohol (S3): ${ }^{1} \mathrm{H} \mathrm{NMR}\left(300 \mathrm{MHz}, \mathrm{CDCl}_{3}\right) \delta$ 7.24-7.37 (m, $\left.10 \mathrm{H}\right), 5.60$ (br, 1H), $4.04 \& 4.00$ (s, 2H), 3.66-3.70 (m, 1H), 3.20-3.26 (m, 1H), $3.16 \& 3.11(\mathrm{~s}, 2 \mathrm{H}), 2.50-2.58(\mathrm{~m}$, 
$1 \mathrm{H}), 2.44-2.46(\mathrm{~m}, 1 \mathrm{H}), 1.99-2.10(\mathrm{~m}, 1 \mathrm{H}), 1.25-1.33(\mathrm{~m}, 1 \mathrm{H}), 0.96-1.02(\mathrm{~m}, 1 \mathrm{H}), 0.84-0.89(\mathrm{t}, \mathrm{J}=7.2$ $\mathrm{Hz}, 3 \mathrm{H}) .{ }^{13} \mathrm{C} \mathrm{NMR}\left(75 \mathrm{MHz}, \mathrm{CDCl}_{3}\right): 138.2,129.5,128.8,127.6,69.3,60.4,59.4,36.4,32.5,20.6,14.6$. TOF-MS-ESI: $[\mathrm{M}+\mathrm{H}]^{+}$calculated 298.2, found 298.5, $[\mathrm{M}+\mathrm{Na}]^{+}$calculated 320.2, found 320.5; $[2 \mathrm{M}+\mathrm{Na}]^{+}$calculated 617.4, found 618.1. Optical rotation: $[\alpha]_{\mathrm{D}}^{\mathrm{rt}}=+18.0^{\circ}(c=0.25, \mathrm{MeOH}$; as $\mathrm{HCl}$ salt $)$. $49 \%$ ee [Chiracel OD column; 95/5 hexane/isopropanol; flow rate $=1 \mathrm{~mL} / \mathrm{min} ; \mathrm{T}_{R} 1: 7.8 \mathrm{~min}$ (minor), $\mathrm{T}_{R} 2: 8.9$ (major)].

(S)- $\beta$-Propyl- $\gamma$ - Boc amino alcohol (S4): Optical rotation: $[\alpha]^{\mathrm{rt}}=+3.4^{\circ}(c=0.20, \mathrm{MeOH})$.

\section{Table 1. Salt effect:}

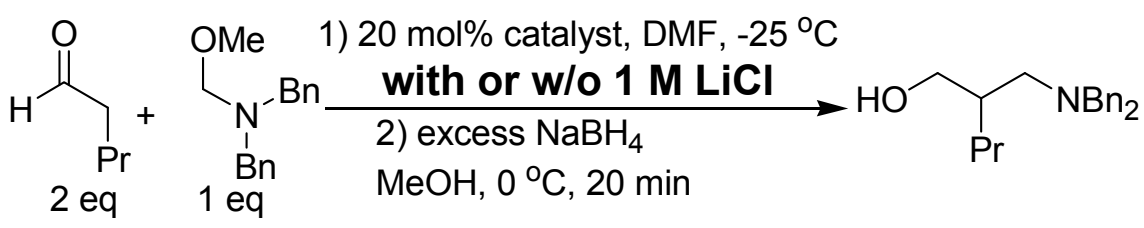

\begin{tabular}{|c|c|c|c|c|c|}
\hline entry $^{\mathrm{a}}$ & catalyst & salt & time & $e^{b}$ & $\begin{array}{c}\text { favored } \\
\text { enantiomer } \\
\end{array}$ \\
\hline 1 & L-proline & -- & $24 \mathrm{~h}$ & 49 & $\bar{S}$ \\
\hline 2 & L-proline & $\mathrm{LiCl}$ & $24 \mathrm{~h}$ & $<5$ & -- \\
\hline 3 & C-HOAc & -- & $2 \mathrm{~h}$ & 67 & $\mathrm{R}$ \\
\hline 4 & C-HOAc & $\mathrm{LiCl}$ & $2 \mathrm{~h}$ & 80 & $\mathrm{R}$ \\
\hline 5 & B-HOAc & -- & $2 \mathrm{~h}$ & 22 & $\mathrm{R}$ \\
\hline 6 & B-HOAc & $\mathrm{LiCl}$ & $2 \mathrm{~h}$ & 29 & $\mathrm{R}$ \\
\hline 7 & F-HOAc & -- & $2 \mathrm{~h}$ & 83 & $\mathrm{R}$ \\
\hline 8 & F-HOAc & $\mathrm{LiCl}$ & $2 \mathrm{~h}$ & 92 & $\mathrm{R}$ \\
\hline
\end{tabular}

General Procedures: To $0.1 \mathrm{mmol}$ catalyst dissolved in $1 \mathrm{~mL}$ biotech grade DMF (or $1 \mathbf{~ M ~ L i C l ~ D M F ~}$ solution $\left.{ }^{3}\right)$ in an $8 \mathrm{~mL}$ vial at $-25^{\circ} \mathrm{C}$ was added $110 \mu \mathrm{L}(1 \mathrm{mmol})$ pentanal. The mixture was stirred for a few minutes, and $127 \mu \mathrm{L}(0.5 \mathrm{mmol}) \mathrm{N}, \mathrm{O}$-acetal $\mathbf{A}$ was added. The vial was capped and the mixture was stirred at $-25{ }^{\circ} \mathrm{C}$ for 2 or 24 hours. Yield of the reaction was determined by ${ }^{1} \mathrm{H}$ NMR analysis of the crude reaction mixture. ${ }^{4}$ Excess $\mathrm{NaBH}_{4}(0.06 \mathrm{~g}, 1.5 \mathrm{mmol})$ was added, followed by the addition of $1 \mathrm{~mL}$ $\mathrm{MeOH}$, and the mixture was stirred for a few minutes. The $-25^{\circ} \mathrm{C}$ cooling bath was replaced by an ice bath, and the mixture was stirred for another 20 minutes. The mixture was then slowly poured into a 24 $\mathrm{mL}$ vial containing $5 \mathrm{~mL}$ saturated $\mathrm{NH}_{4} \mathrm{Cl}$ at $0{ }^{\circ} \mathrm{C}$ and extracted with $10 \mathrm{~mL} \mathrm{Et}_{2} \mathrm{O}$. The $\mathrm{Et}_{2} \mathrm{O}$ layer was collected, washed with $5 \mathrm{~mL}$ water and then $5 \mathrm{~mL}$ brine, dried over $\mathrm{MgSO}_{4}$, filtered and concentrated to give a colorless oil. The oil was dissolved in a mixture of hexane/isopropanol (v/v; 90/10) and used for ee determination without further purification. The corresponding racemic Mannich product was obtained by using D,L-proline as catalyst for ee assay development. The ee determination was performed on a Shimadzu 10A HPLC using a Chiracel OD column. Mobile phase: hexane/isopropanol (v/v: 95/5, premixed); flow rate $=1 \mathrm{~mL} / \mathrm{min}$; retention time: $\sim 7.8$ minutes and $\sim 8.9$ minutes. Shown below are selected HPLC chromatograms:

\footnotetext{
${ }^{3}$ Concentration of $\mathrm{LiCl}$ refers to room temperature concentration. At $-25^{\circ} \mathrm{C}, \mathrm{LiCl}$ partially precipitates.

${ }^{4}{ }^{1} \mathrm{H}$ NMR analysis: $50 \mu \mathrm{L}$ crude reaction mixture was mixed with $650 \mu \mathrm{LCDCl}_{3}$ for NMR analysis. NMR condition: RG (gain) $=1$, NS $=32$.
} 

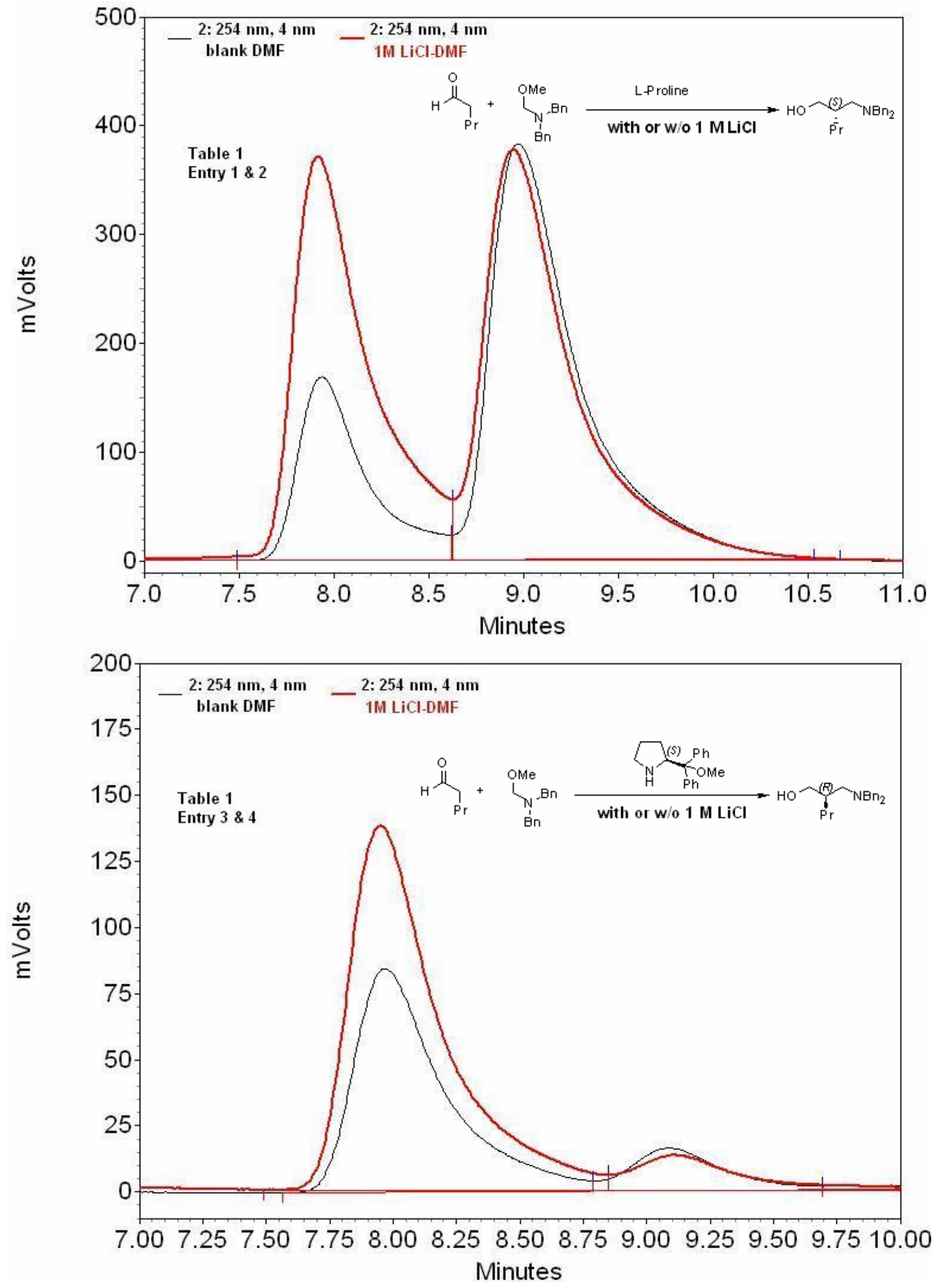
Table 2. Enantioselective aminomethylation of aldehydes

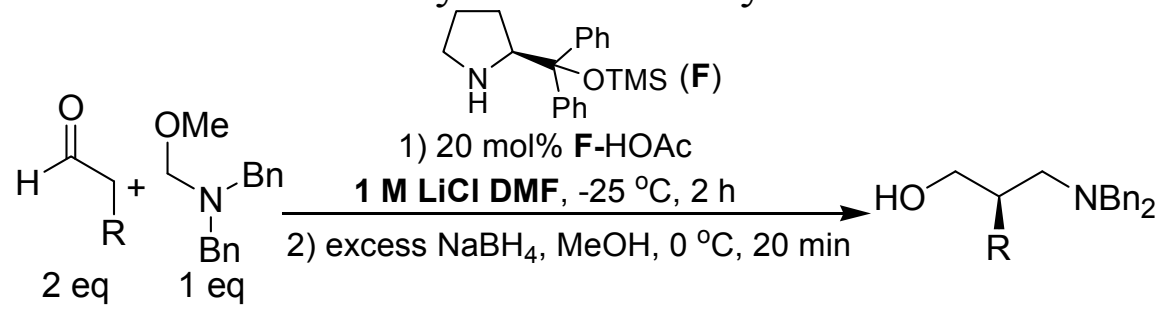

\begin{tabular}{cccccc}
\hline entry & product \# & $\mathrm{R}$ & $\begin{array}{c}\text { TLC R } \\
(\mathrm{v} / \mathrm{v}, \text { EtOAc/Hexane })\end{array}$ & ${\text { isolated yield }(\%)^{\mathrm{a}}}^{\text {ee }(\%)^{\mathrm{b}}}$ & \\
\hline 1 & $\mathbf{S 5}$ & $\mathrm{Et}$ & $0.12(1 / 5)$ & 84 & 90 \\
2 & $(R)-\mathbf{S 3}$ & $\mathrm{Pr}$ & $0.14(1 / 5)$ & 87 & 92 \\
3 & $\mathbf{S 6}$ & $i-\mathrm{Pr}$ & $0.13(1 / 5)$ & 86 & 91 \\
4 & $\mathbf{S 7}$ & $\mathrm{Bn}$ & $0.081(1 / 5)$ & 81 & 92 \\
5 & $\mathbf{S 8}$ & $\mathrm{MeO}_{2} \mathrm{CCH}_{2}$ & $0.36(1 / 2)$ & 65 & 90 \\
\hline
\end{tabular}

${ }^{a}$ Yield of isolated amino alcohol after column chromatography on silica gel. ${ }^{b}$ Ee of amino alcohol determined by chiral phase HPLC.

General Procedures: To $0.33 \mathrm{~g}(1 \mathrm{mmol}){ }^{5}$ catalyst $\mathbf{F}$ dissolved in $9 \mathrm{~mL} 1 \mathrm{M} \mathrm{LiCl}$ DMF in a $100 \mathrm{~mL}$ round bottom flask at $-25{ }^{\circ} \mathrm{C}$ was added $57 \mu \mathrm{L}(1 \mathrm{mmol}) \mathrm{HOAc}$ (in $\left.1 \mathrm{~mL} 1 \mathrm{M} \mathrm{LiCl} \mathrm{DMF}\right)$. Aldehyde (neat, $10 \mathrm{mmol}$ ) was added, and the mixture was stirred for a few minutes. N,O-acetal $\mathbf{A}$ (neat, $1.27 \mathrm{~mL}$, $5 \mathrm{mmol}$ ) was added. The flask was capped, and the mixture was stirred at $-25{ }^{\circ} \mathrm{C}$ for 2 hours. Excess $\mathrm{NaBH}_{4}(0.57 \mathrm{~g}, 15 \mathrm{mmol})$ was added, followed by the addition of $10 \mathrm{~mL} \mathrm{MeOH}$, and the mixture was stirred for a few minutes. The $-25^{\circ} \mathrm{C}$ cooling bath was replaced by an ice bath, and the mixture was stirred for another 20 minutes. The mixture was then slowly poured into a $250 \mathrm{~mL}$ beaker containing 50 $\mathrm{mL}$ saturated $\mathrm{NH}_{4} \mathrm{Cl}$ at $0{ }^{\circ} \mathrm{C}$ and extracted with $\mathrm{Et}_{2} \mathrm{O}$ (about $3 \times 100 \mathrm{~mL}$ ). Complete extraction of the product to the organic phases was monitored by TLC analysis. The $\mathrm{Et}_{2} \mathrm{O}$ layers were collected, washed with $50 \mathrm{~mL}$ water and then $50 \mathrm{~mL}$ brine, dried over $\mathrm{MgSO}_{4}$, filtered and concentrated to give crude $\beta$ substituted $\gamma$-amino alcohols, which were purified via flash column chromatography eluted with EtOAc/Hexane $(1: 10 ; \mathrm{v} / \mathrm{v})^{6}$ to give the desired products as colorless viscous oils. This oil was used directly for ee determination and NMR characterizations (no recrystallization). ${ }^{7}$

(R)- $\boldsymbol{\beta}$-Ethyl- $\boldsymbol{\gamma}$-dibenzylamino alcohol (S5) (Table 2, entry 1): ${ }^{1} \mathrm{H}$ NMR $(300 \mathrm{MHz}$, $\left.\mathrm{CDCl}_{3}\right) \delta 7.25-7.37(\mathrm{~m}, 10 \mathrm{H}), 5.59(\mathrm{br}, 1 \mathrm{H}), 4.05 \& 4.00(\mathrm{~s}, 2 \mathrm{H}), 3.68-3.74(\mathrm{~m}, 1 \mathrm{H})$, $3.21-3.28(\mathrm{~m}, 1 \mathrm{H}), 3.13 \& 3.17(\mathrm{~s}, 2 \mathrm{H}), 2.51-2.59(\mathrm{~m}, 1 \mathrm{H}), 2.43-2.48(\mathrm{~m}, 1 \mathrm{H}), 1.98$ $(\mathrm{m}, 1 \mathrm{H}), 1.06(\mathrm{td}, \mathrm{J}=6.3,7.5 \mathrm{~Hz}, 2 \mathrm{H}), 0.88(\mathrm{t}, \mathrm{J}=7.5 \mathrm{~Hz}, 3 \mathrm{H}) .{ }^{13} \mathrm{C} \mathrm{NMR}(75 \mathrm{MHz}$,<smiles>CC[C@H](CO)CN(Cc1ccccc1)Cc1ccccc1</smiles>
S5 $\left.\mathrm{CDCl}_{3}\right): 138.1,129.5,128.7,127.6,68.9,60.1,59.3,38.4,23.1,12.1$. TOF-MS-ESI: $[\mathrm{M}+\mathrm{H}]^{+}$calculated 284.2, found 284.5; [M+Na $]^{+}$calculated 306.2, found 306.5; [2M+Na] ${ }^{+}$calculated 589.4, found 590.0. Optical rotation: $[\alpha]_{\mathrm{D}}^{\mathrm{rt}}=+16.8^{\circ}(c=0.13, \mathrm{MeOH}$; as $\mathrm{HCl}$ salt $) .90 \%$ ee [Chiracel OD column; 95/5 hexane/isopropanol; flow rate $=1 \mathrm{~mL} / \mathrm{min} ; \mathrm{T}_{R} 1: 8.0 \mathrm{~min}$ (major), $\mathrm{T}_{R} 2: 10.8 \mathrm{~min}$ (minor)].

(R)- $\beta$-Ppropyl- $\gamma$-dibenzylamino alcohol $\left[(R)-\right.$ S3] (Table 2, entry 2): Optical rotation: $[\alpha]_{D}^{\mathrm{rt}}=-32.4^{\circ}(c$ $=0.25, \mathrm{MeOH}$; as $\mathrm{HCl}$ salt). $92 \%$ ee [Chiracel ODH column; 95/5 hexane/isopropanol; flow rate $=1$ $\mathrm{mL} / \mathrm{min} ; \mathrm{T}_{R} 1: 7.26 \mathrm{~min}$ (major), $\mathrm{T}_{R} 2: 8.20 \mathrm{~min}$ (minor)].

\footnotetext{
${ }^{5}$ The reaction scale in Table 2 is larger than the scale in Table 1 in order to get accurate isolated yield and demonstrate reaction scope. It should be noted that the Mannich reaction gave comparable yield and ee at different reaction scales.

${ }^{6}$ We used 1:5 or 1:2 (v/v) EtOAc/hexane for TLC analysis and 1:10 EtOAc/hexane for column chromatography.

${ }^{7}$ Optical rotation measurements were performed using the $\mathrm{HCl}$ salt of the amino alcohol before recrystallization.
} 
(R)- $\beta$-Isopropyl- $\gamma$-dibenzylamino alcohol (S6) (Table 2, entry 3 ): ${ }^{1} \mathrm{H}$ NMR (300 $\left.\mathrm{MHz}, \mathrm{CDCl}_{3}\right) \delta$ 7.24-7.36 (m, 10H), $5.62(\mathrm{~m}, 1 \mathrm{H}), 4.04 \& 4.00(\mathrm{~s}, 2 \mathrm{H}), 3.69-3.74$ $(\mathrm{m}, 1 \mathrm{H}), 3.30-3.34(\mathrm{~m}, 1 \mathrm{H}), 3.17 \& 3.13(\mathrm{~s}, 2 \mathrm{H}), 2.64-2.72(\mathrm{~m}, 1 \mathrm{H}), 2.44-2.50(\mathrm{~m}$, $1 \mathrm{H}), 1.88-1.94(\mathrm{~m}, 1 \mathrm{H}), 1.44-1.51(\mathrm{~m}, 1 \mathrm{H}), 0.83 \& 0.81$ (diastereotopic, $\mathrm{d}, \mathrm{J}=6.7$<smiles>CC(C)C(CO)CN(Cc1ccccc1)Cc1ccccc1</smiles>

S6

$\mathrm{Hz}, 6 \mathrm{H}) .{ }^{13} \mathrm{C}$ NMR $\left(75 \mathrm{MHz}, \mathrm{CDCl}_{3}\right): \delta 138.1,129.5,128.7,127.6,67.2,59.3,57.9,42.1,28.8,20.4$, 20.0. TOF-MS-ESI: $[\mathrm{M}+\mathrm{H}]^{+}$calculated 298.2, found 298.5; $[\mathrm{M}+\mathrm{Na}]^{+}$calculated 320.2, found 320.5; $[2 \mathrm{M}+\mathrm{Na}]^{+}$calculated 617.4, found 618.1. Optical rotation: $[\alpha]_{\mathrm{D}}^{\mathrm{tt}}=-29.5^{\circ}(c=0.20, \mathrm{MeOH}$; as $\mathrm{HCl}$ salt $)$. $91 \%$ ee [Chiracel OD column; 95/5 hexane/isopropanol; flow rate $=1 \mathrm{~mL} / \mathrm{min} ; \mathrm{T}_{R} 1: 7.2 \mathrm{~min}$ (major), $\mathrm{T}_{R}$ 2: $8.6 \mathrm{~min}$ (minor)].

(R)- $\beta$-Benyl- $\gamma$-dibenzylamino alcohol (S7) (Table 2, entry 4): ${ }^{1} \mathrm{H}$ NMR $(300 \mathrm{MHz}$, $\left.\mathrm{CDCl}_{3}\right) \delta$ 7.09-7.35 (m, 15H), $3.95 \& 3.90(\mathrm{~s}, 2 \mathrm{H}), 3.64-3.69(\mathrm{~m}, 1 \mathrm{H}), 3.13-3.34(\mathrm{~m}$, $1 \mathrm{H}), 3.18 \& 3.13(\mathrm{~s}, 2 \mathrm{H}), 2.28-2.58(\mathrm{~m}, 5 \mathrm{H}) .{ }^{13} \mathrm{C}$ NMR $\left(75 \mathrm{MHz}, \mathrm{CDCl}_{3}\right): \delta 140.1$, $138.0,129.5,129.1,128.7,128.6,127.6,126.3,68.5,59.2,59.0,38.7,36.6$. TOF-<smiles>OCC(Cc1ccccc1)CN(Cc1ccccc1)Cc1ccccc1</smiles>

S7 MS-ESI: $[\mathrm{M}+\mathrm{H}]^{+}$calculated 346.2, found 346.6. Optical rotation: $[\alpha]^{\mathrm{rt}}=-44.1^{\circ}(c=0.14, \mathrm{MeOH}$; as $\mathrm{HCl}$ salt). $92 \%$ ee [Chiracel OD column; $95 / 5$ hexane/isopropanol; flow rate $=1 \mathrm{~mL} / \mathrm{min} ; \mathrm{T}_{R} 1: 13.2 \mathrm{~min}$ (major), $\mathrm{T}_{R} 2: 19.5 \mathrm{~min}$ (minor)].

S8 (Table 2, entry 6): ${ }^{1} \mathrm{H}$ NMR (300 MHz, $\left.\mathrm{CDCl}_{3}\right) \delta$ 7.25-7.36 (m, 10H), $4.64(\mathrm{br}$, $1 \mathrm{H}), 4.14 \& 4.16(\mathrm{~s}, 2 \mathrm{H}), 3.65(\mathrm{~s}, 3 \mathrm{H}), 3.63-3.69(\mathrm{~m}, 1 \mathrm{H}), 3.33-3.39(\mathrm{~m}, 1 \mathrm{H}), 3.26$ \& $3.22(\mathrm{~s}, 2 \mathrm{H}), 2.42-2.58(\mathrm{~m}, 3 \mathrm{H}), 2.11(\mathrm{~d}, 6.0 \mathrm{~Hz}, 2 \mathrm{H}) .{ }^{13} \mathrm{C} \mathrm{NMR}(75 \mathrm{MHz}$, $\left.\mathrm{CDCl}_{3}\right): \delta 137.1,128.3,129.4,128.7,127.6,67.4,59.1,57.9,51.9,34.9,34.4$. TOFMS-ESI: $[\mathrm{M}+\mathrm{H}]^{+}$calculated 328.2 , found 328.5 . Optical rotation: $[\alpha]^{\mathrm{rt}}=-24.7^{\circ}(c$ $=0.20, \mathrm{MeOH} ;$ as $\mathrm{HCl}$ salt). $\sim 90 \%$ ee [Chiracel OD column; 95/5

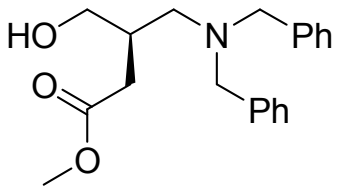

S8 hexane/isopropanol; flow rate $=1 \mathrm{~mL} / \mathrm{min} ; \mathrm{T}_{R} 1: 16.4 \mathrm{~min}$ (major), $\mathrm{T}_{R} 2: 19.6 \mathrm{~min}$ (minor)].

\section{Scheme 2. Concise synthesis of $\beta^{2}$-amino acid:}

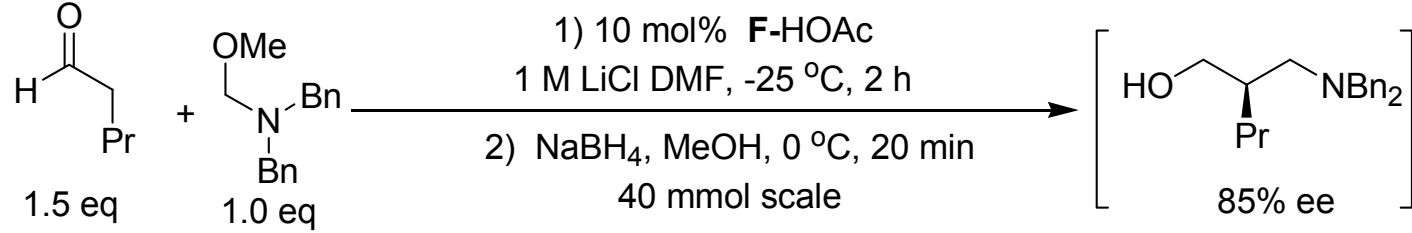

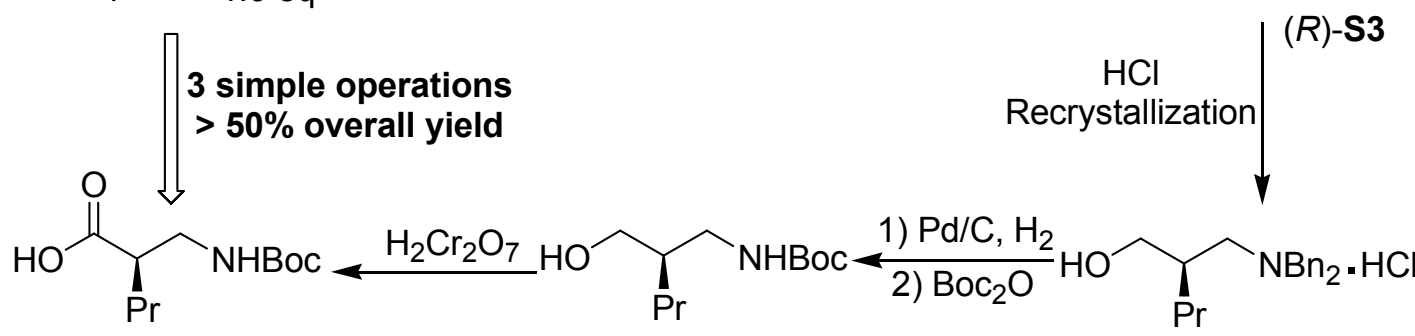

S5

$(R)-\mathrm{S} 4$

$>80 \%$ isolated yield
$>90 \%$ isolated yield
$(R)-\mathrm{S} 3 \cdot \mathrm{HCl}$

$72 \%$ isolated yield $>98 \%$ ee 
(R)-S3-HCl: The Mannich reaction/reduction sequence followed the general procedures described above for Table 2; except that $10 \mathrm{~mol} \%$ catalyst was used in this case (to minimize catalyst quantity). This procedure provided $(R)-\mathbf{S 3}$ as a viscous oil in quantitative yield with $\sim 85 \%$ ee. ( $R$ )-S3 was dissolved in $50 \mathrm{~mL} \mathrm{Et}{ }_{2} \mathrm{O}$, followed by the slow addition of $50 \mathrm{~mL} 4 \mathrm{~N} \mathrm{HCl}$ in dioxane. The resulting mixture was stirred for a few minutes and the solvent was removed under reduced pressure to give a viscous oil. To this viscous oil in a $150 \mathrm{~mL}$ flask, was added $50 \mathrm{~mL}$ EtOAc. The flask was shaken with heating (with a heat gun) until the oil solidified in ethyl acetate to give a milky mixture with white solid. A few drops of $\mathrm{MeOH}$ were added to the milky mixture until the solid was just completely dissolved to give a clear solution. The open flask with the EtOAc-MeOH hot solution was then kept in a glass container containing hot $\mathrm{Et}_{2} \mathrm{O}$. The container was sealed and stayed at room temperature for crystallization. Crystals from this procedures were filtered, washed with EtOAc and dried in vacuo to afford $9.6 \mathrm{~g} \mathrm{(72 \%}$ yield) (R)-S3-HCl as white crystals with $>98 \%$ ee (determined using the free amino alcohol after a base wash of the $\mathrm{HCl}$ salt $).{ }^{8}$ Melting point: $135-137{ }^{\circ} \mathrm{C}$. Optical rotation: $[\alpha]^{\mathrm{rt}} \mathrm{D}=-36.3^{\circ}(c=0.25, \mathrm{MeOH}$; as $\mathrm{HCl}$ salt).

(R)-S4: (R)-S3-HCl $(5.0 \mathrm{~g}, 15 \mathrm{mmol})$ and wet $10 \% \mathrm{Pd} / \mathrm{C}(1.0 \mathrm{~g})$ were added to $50 \mathrm{~mL} \mathrm{MeOH}$ in a hydrogenation flask. The heterogeneous mixture was put under 40-60 $\mathrm{psi}_{2} \mathrm{H}_{2}$ at room temperature overnight. After the hydrogenolysis was completed as indicted by TLC analysis, the mixture was diluted by $50 \mathrm{~mL} \mathrm{CH}_{2} \mathrm{Cl}_{2}$, and DIEA (26 mmol, $\left.6.4 \mathrm{~mL}\right)$ and $\mathrm{Boc}_{2} \mathrm{O}(18 \mathrm{mmol}, 4.0 \mathrm{~g})$ were added. The mixture was stirred at room temperature overnight and filtered through a pad of celite to remove $\mathrm{Pd} / \mathrm{C}$, and the celite was washed with $\mathrm{MeOH}$ extensively. The filtrate was collected, concentrated and applied to a silica chromatography column eluted with EtOAc/Hexane $\left(1 / 5, \mathrm{v} / \mathrm{v}, \mathrm{TLC} \mathrm{R}_{\mathrm{f}}=0.07\right)$ to give $3.1 \mathrm{~g}(96 \%$ yield) $(R)-\mathbf{S} 4$ as a colorless oil. Optical rotation: $[\alpha]^{\mathrm{rt}}=-7.0^{\circ}(c=0.20, \mathrm{MeOH})$.

(R)-Boc- $\boldsymbol{\beta}^{2}$-Homonovaline-OH (S9): To $2.8 \mathrm{~g}(13 \mathrm{mmol})(R)-\mathbf{S} 4$ dissolved in $130 \mathrm{~mL}$ acetone at $0{ }^{\circ} \mathrm{C}$ was added $19.5 \mathrm{mmol} \mathrm{H}_{2} \mathrm{Cr}_{2} \mathrm{O}_{7}$ (39 mL Jones reagent). ${ }^{9}$ The mixture was stirred for $12 \mathrm{~h}$, during which time the mixture warmed to room temperature. Excess isopropanol was added, and the mixture was stirred overnight. The mixture was filtered, and the solution was concentrated to about $20 \mathrm{~mL}$ under reduced pressure at room temperature. The concentrated mixture was diluted with $20 \mathrm{~mL} 2 \mathrm{~N} \mathrm{HCl}$ and extracted with $\mathrm{Et}_{2} \mathrm{O}$. Complete extraction of the product into the $\mathrm{Et}_{2} \mathrm{O}$ phase was monitored by TLC. The $\mathrm{Et}_{2} \mathrm{O}$ layers were collected, combined and concentrated to about $50 \mathrm{~mL}$. This concentrated $\mathrm{Et}_{2} \mathrm{O}$ solution was extracted with $2 \mathrm{M} \mathrm{NaOH}$ (monitored by TLC). The basic aqueous extracts were collected, combined and washed with $2 \times 10 \mathrm{~mL} \mathrm{Et}_{2} \mathrm{O}$. The basic aqueous solution was then acidified with $2 \mathrm{~N}$ $\mathrm{HCl}$ and extracted with $\mathrm{Et}_{2} \mathrm{O}$ (monitored by $\mathrm{TLC}$ ). The $\mathrm{Et}_{2} \mathrm{O}$ layers were combined, washed with saturated $\mathrm{NaCl}$, dried over $\mathrm{MgSO}_{4}$, filtered and concentrated under reduced pressure to give Boc- $\boldsymbol{\beta}^{2}$ Homonovaline-OH as a viscous colorless oil that is pure by TLC and NMR analysis (present as rotamers on the NMR time scale). ${ }^{1} \mathrm{H}$ NMR $\left(300 \mathrm{MHz}, \mathrm{CDCl}_{3}\right) \delta 10.10(\mathrm{br}, 1 \mathrm{H}), 6.61 \& 4.95(\mathrm{br}, 1 \mathrm{H})$, $3.16-3.36(\mathrm{~m}, 2 \mathrm{H}), 2.54-2.56(\mathrm{~m}, 1 \mathrm{H}), 1.18-1.57(\mathrm{~m}, 13 \mathrm{H}), 0.86(\mathrm{t}, \mathrm{J}=6.9 \mathrm{~Hz}, 3 \mathrm{H}) ;{ }^{13} \mathrm{C} \mathrm{NMR}(75 \mathrm{MHz}$, $\left.\mathrm{CDCl}_{3}\right): \delta 180.7 \& 179.3,158.2 \& 156.2,81.3 \& 79.8,45.9 \& 45.6,42.9 \& 41.6,31.9,28.6,20.5,14.1$. TOF-MS-ESI: [M-H] calculated 230.2, found 230.5; [2M-H] calculated 461.3, found 462.0. Optical rotation: $[\alpha]^{\mathrm{rt}}=-17.5^{\circ}(c=0.33, \mathrm{MeOH})$.

\footnotetext{
${ }^{8}$ A second recrystallization may be needed to get $>98 \%$ ee because the crystallization process is not exactly reproducible. It is highly recommended to check the ee of each recrystallization product before further use.

${ }^{9}$ Jones reagent preparation: To $50 \mathrm{mmol} \mathrm{Na}_{2} \mathrm{Cr}_{2} \mathrm{O}_{7}$ dissolved in $50 \mathrm{~mL} \mathrm{H}_{2} \mathrm{O}$, was slowly added 200 mol concentrated $\mathrm{H}_{2} \mathrm{SO}_{4}$. The solution was then diluted to $100 \mathrm{~mL}$ to give the Jones reagent $\left(0.5 \mathrm{M} \mathrm{H}_{2} \mathrm{Cr}_{2} \mathrm{O}_{7}\right)$.
} 


\section{Selected NMR Spectrum:}

\section{S1- ${ }^{1}$ HNMR}
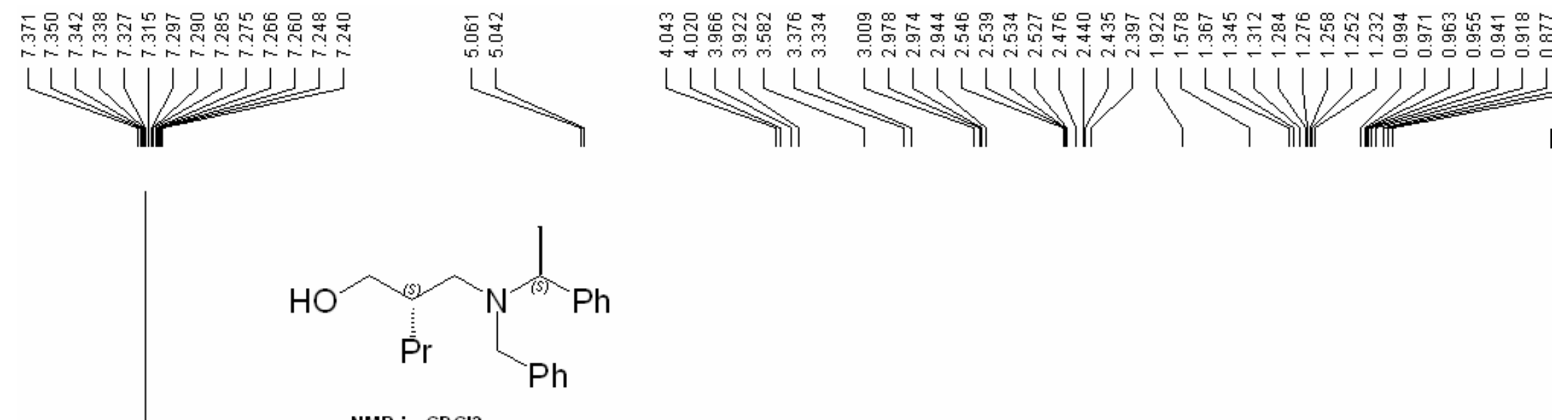

NMR in $\mathrm{CDCl} 3$

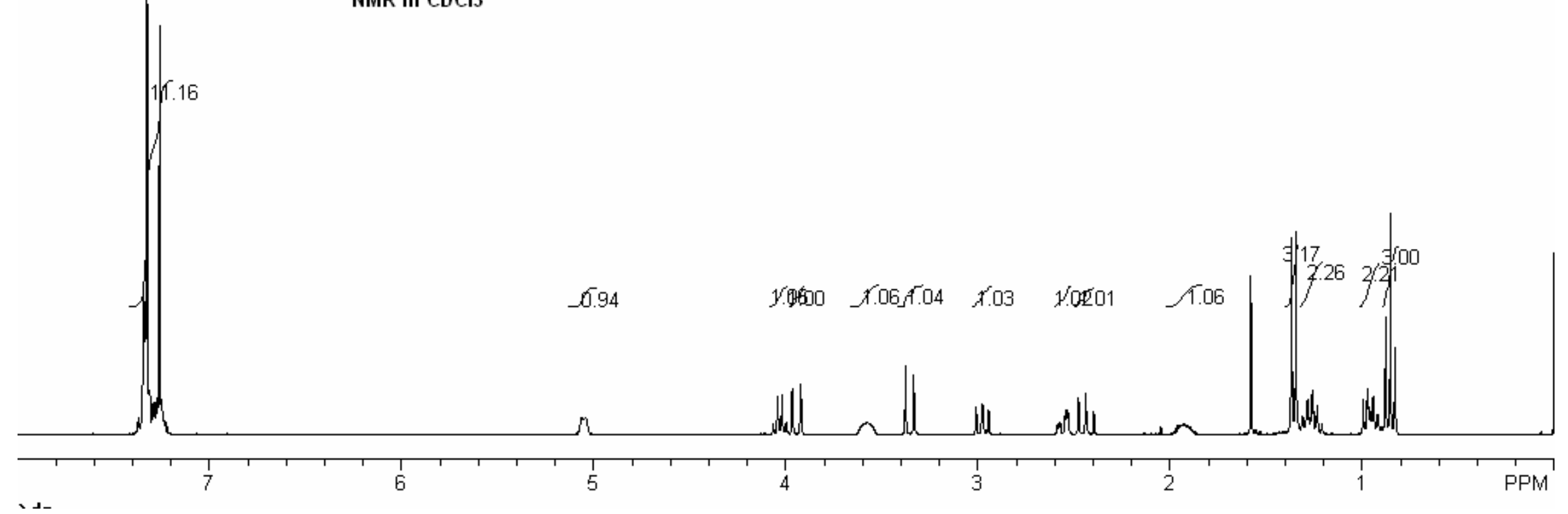


S1- ${ }^{13} \mathrm{C}$ NMR:
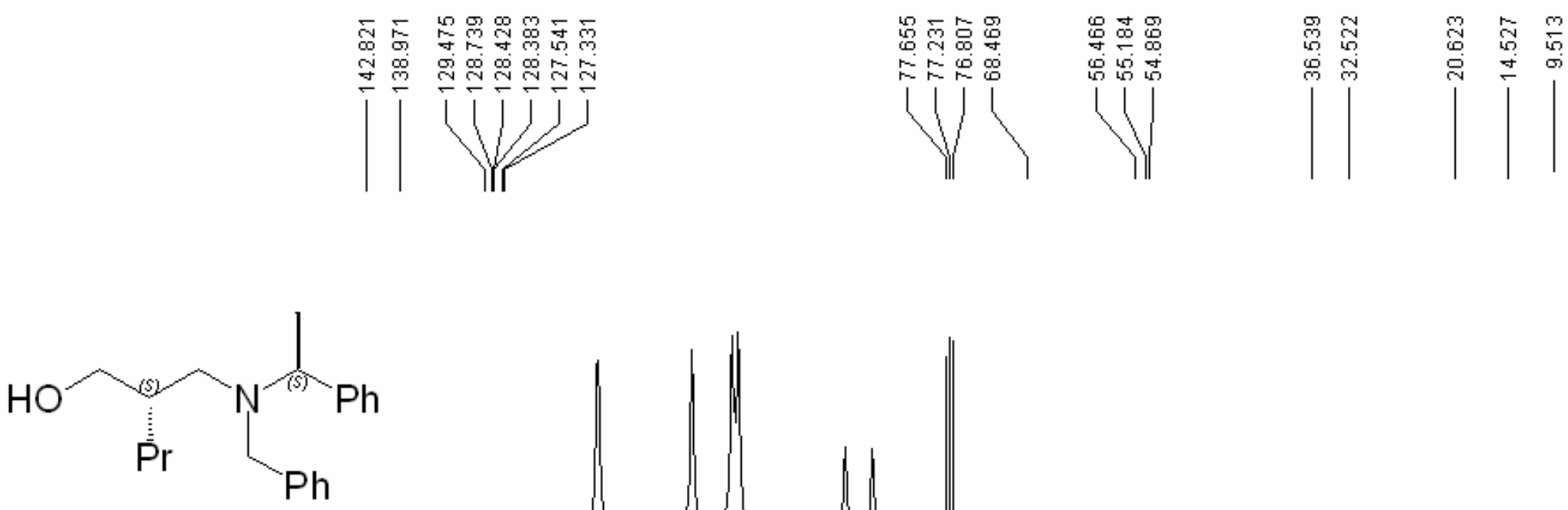

NMR in $\mathrm{CDCl} 3$
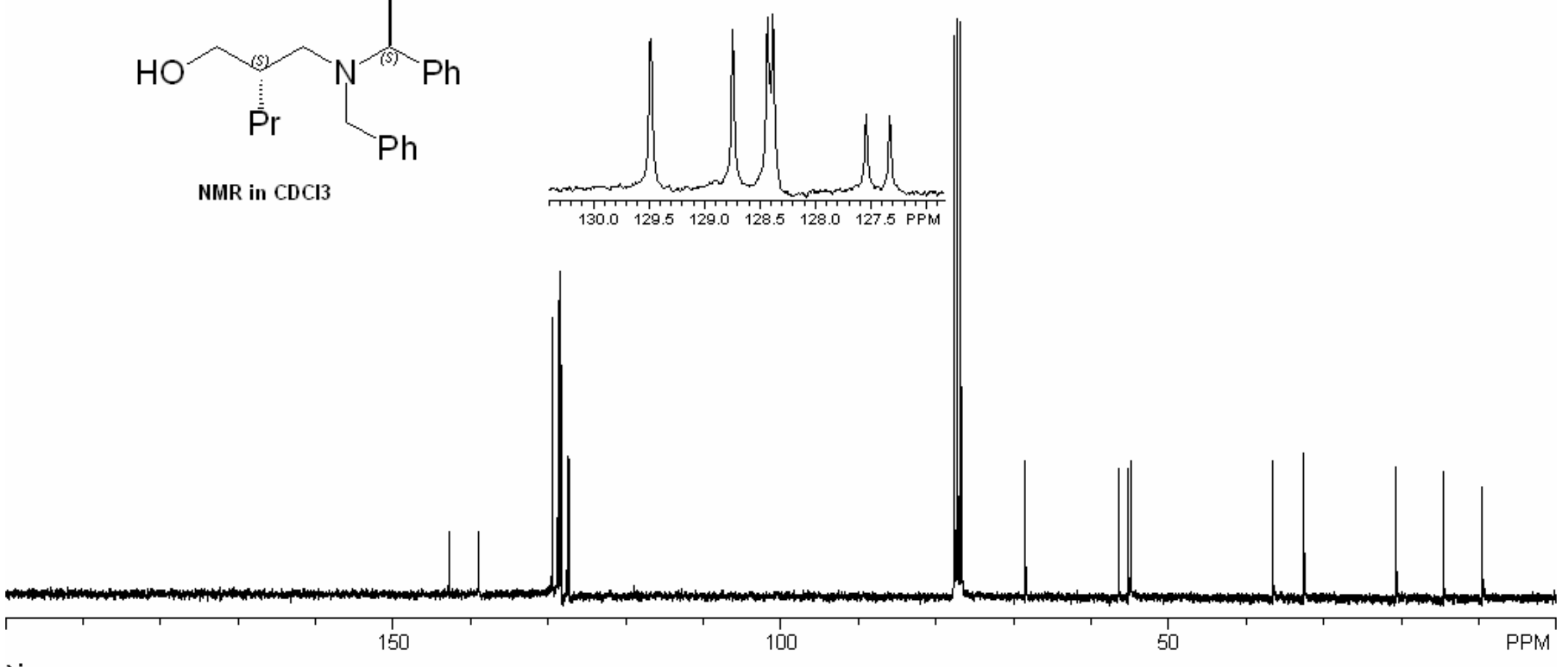
S2- ${ }^{1} \mathrm{H}$ NMR:

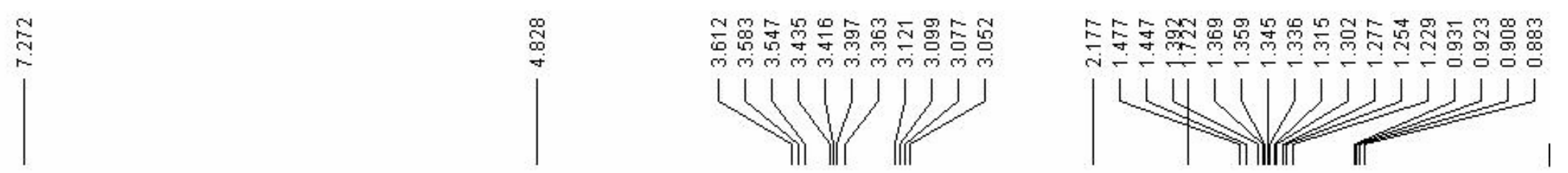

HO $\overbrace{\mathrm{Pr}}^{\mathrm{NH} H O C O}$

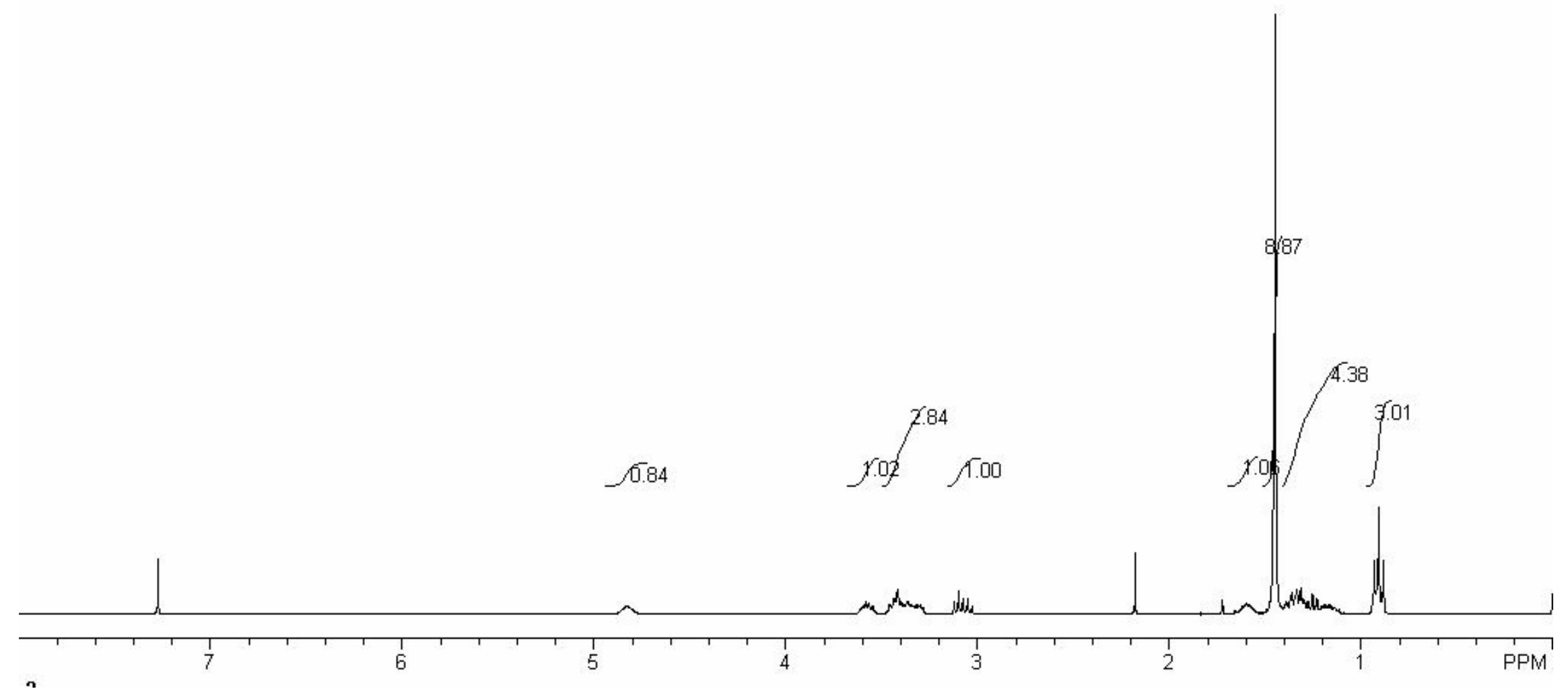


S2 $-{ }^{13} \mathrm{C}$ NMR:
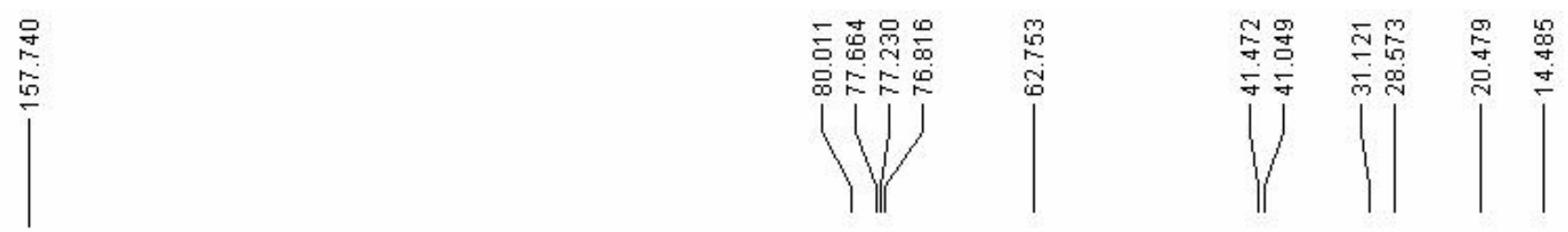

HO $\underset{\text { Prr }}{\text { NHBoc }}$

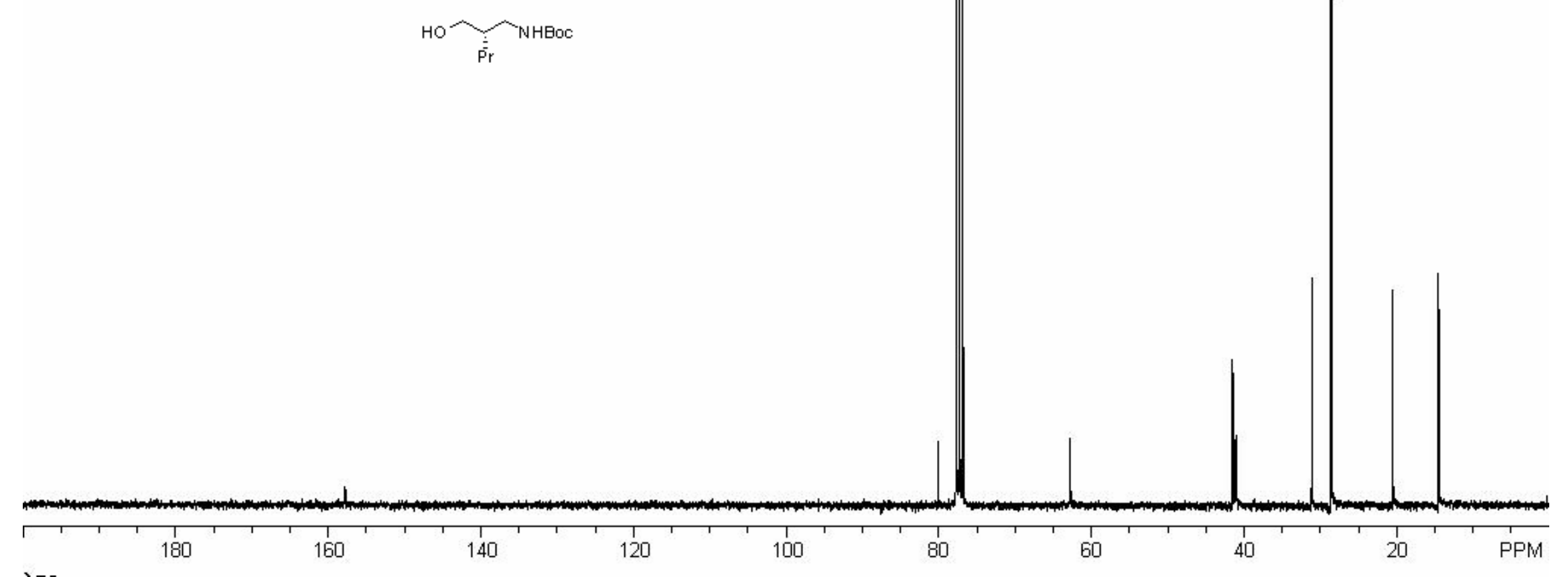




\section{(R)-S3-1H NMR:}

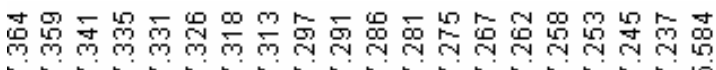

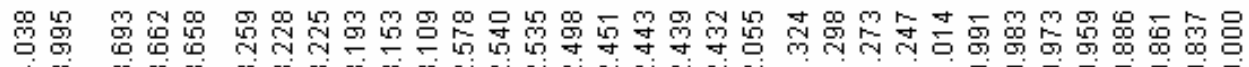
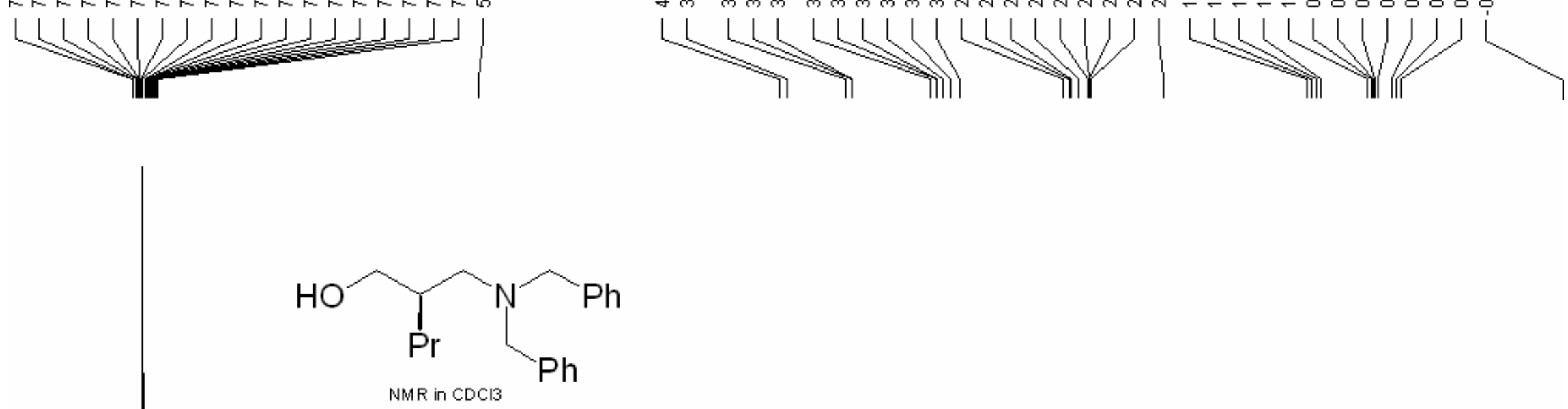

NMR in $\mathrm{CDCl} 3$

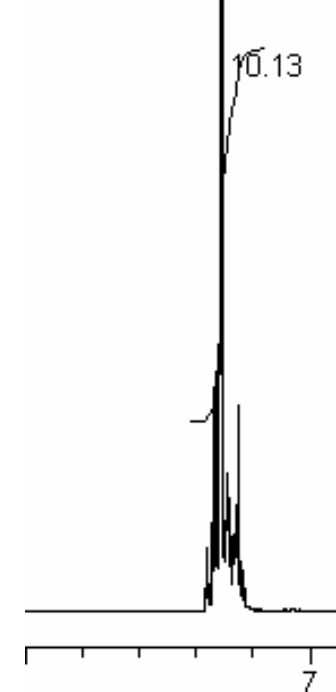


(R)-S3- ${ }^{13} \mathrm{C}$ NMR:
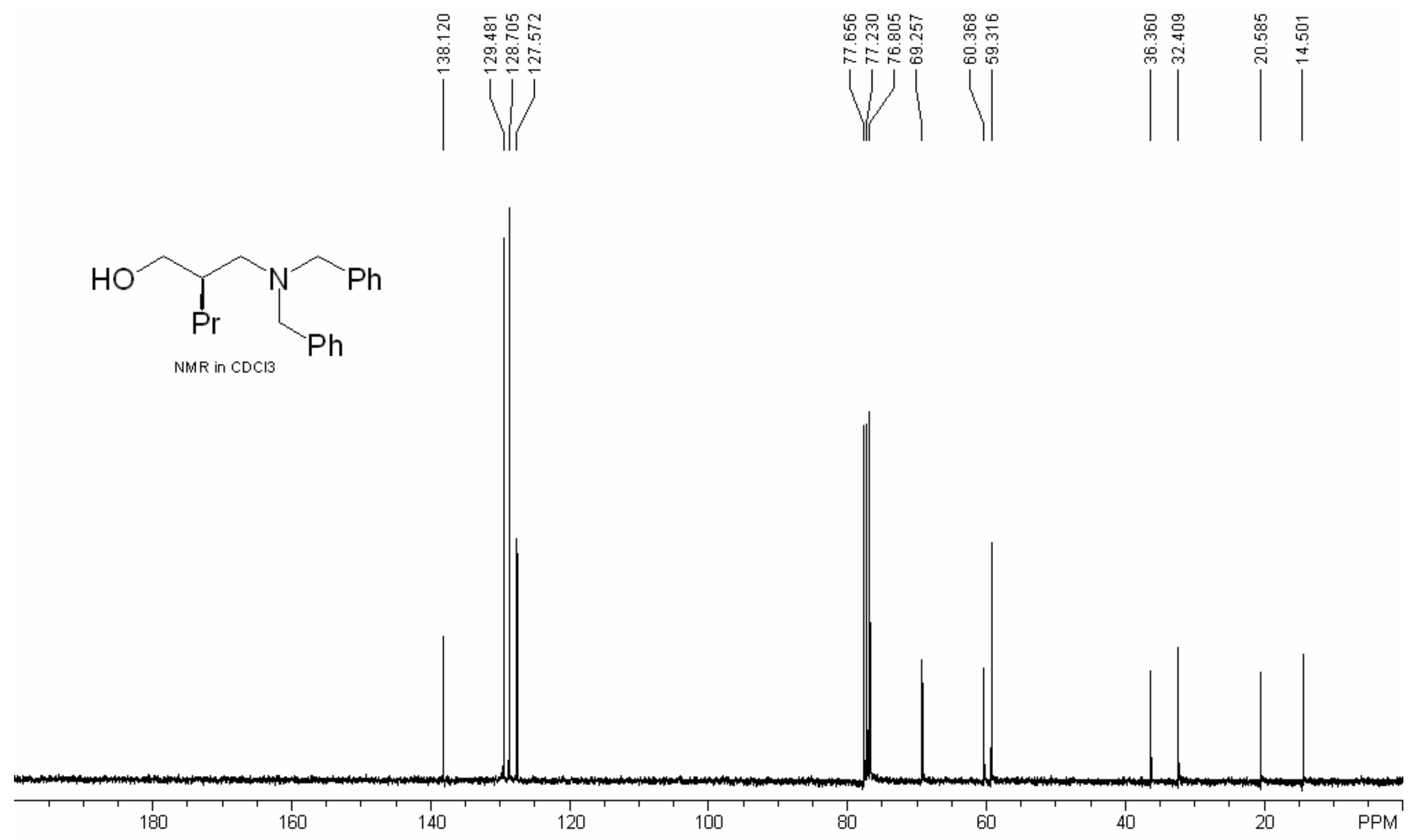
S9- ${ }^{1} \mathrm{H}$ NMR:

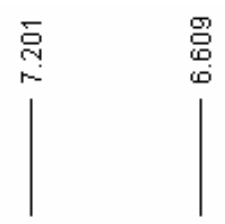

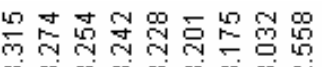

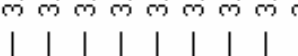

$\sqrt{3.18}$

\section{H NMR in $\mathrm{CDCl} 3$ (exist as rotamers)}

$$
\mathrm{Pr}_{\mathrm{Pr}}^{\mathrm{O}} \mathrm{NHBoC}
$$

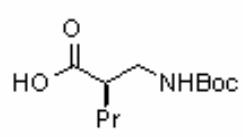

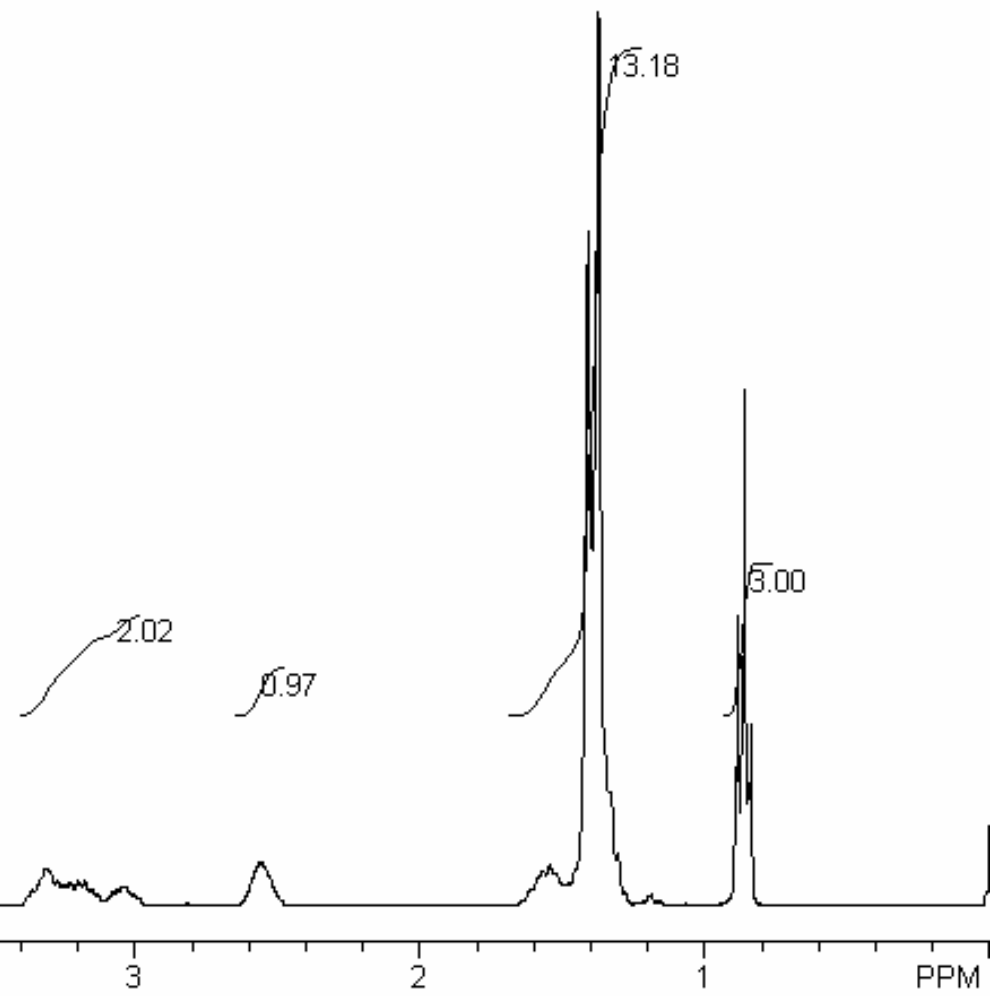

n 
S9- ${ }^{13} \mathrm{C} \mathrm{NMR}$
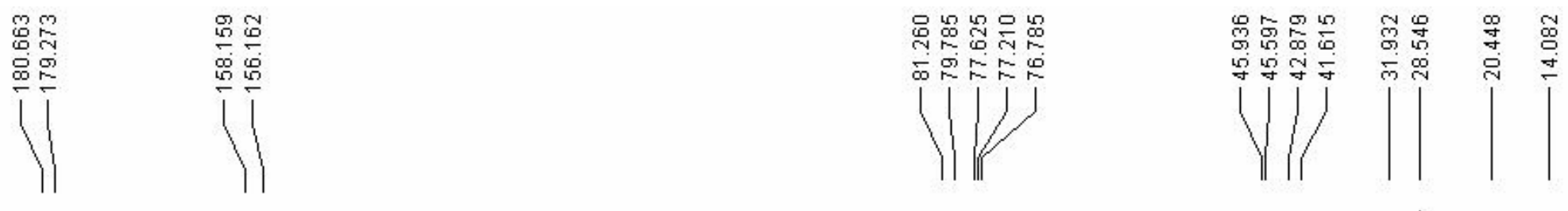

$$
\overbrace{\mathrm{Pr}}^{\mathrm{O}} \mathrm{NHBoc}
$$

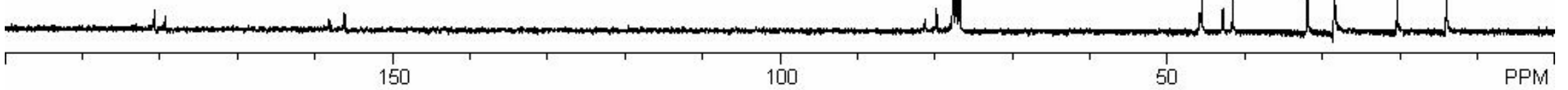


HPLC Chromatograph of ee determination (Table 2 \& Recrystallized (R)-S3):

Table 2, entry 1:

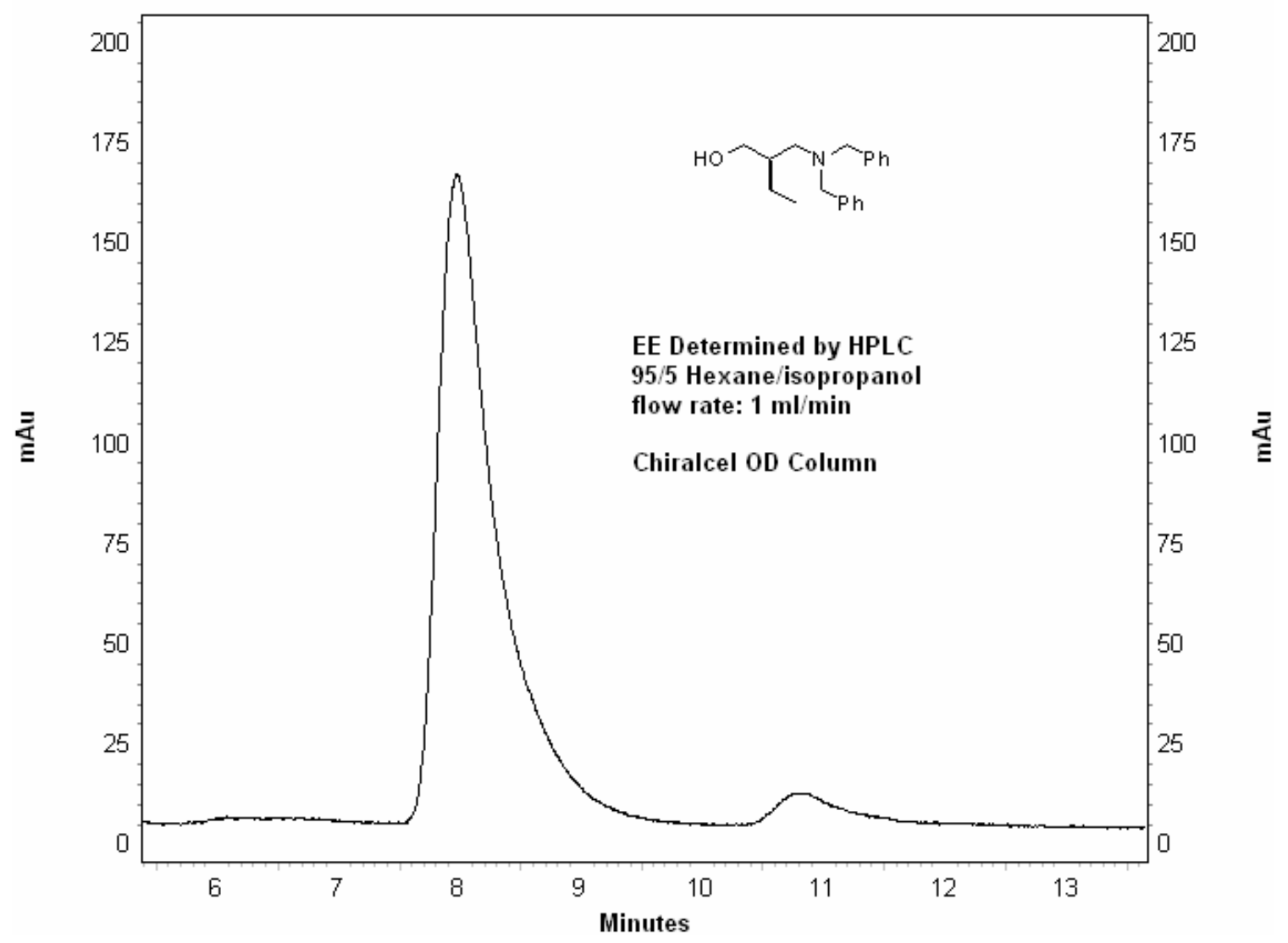

Table 2, entry 2:

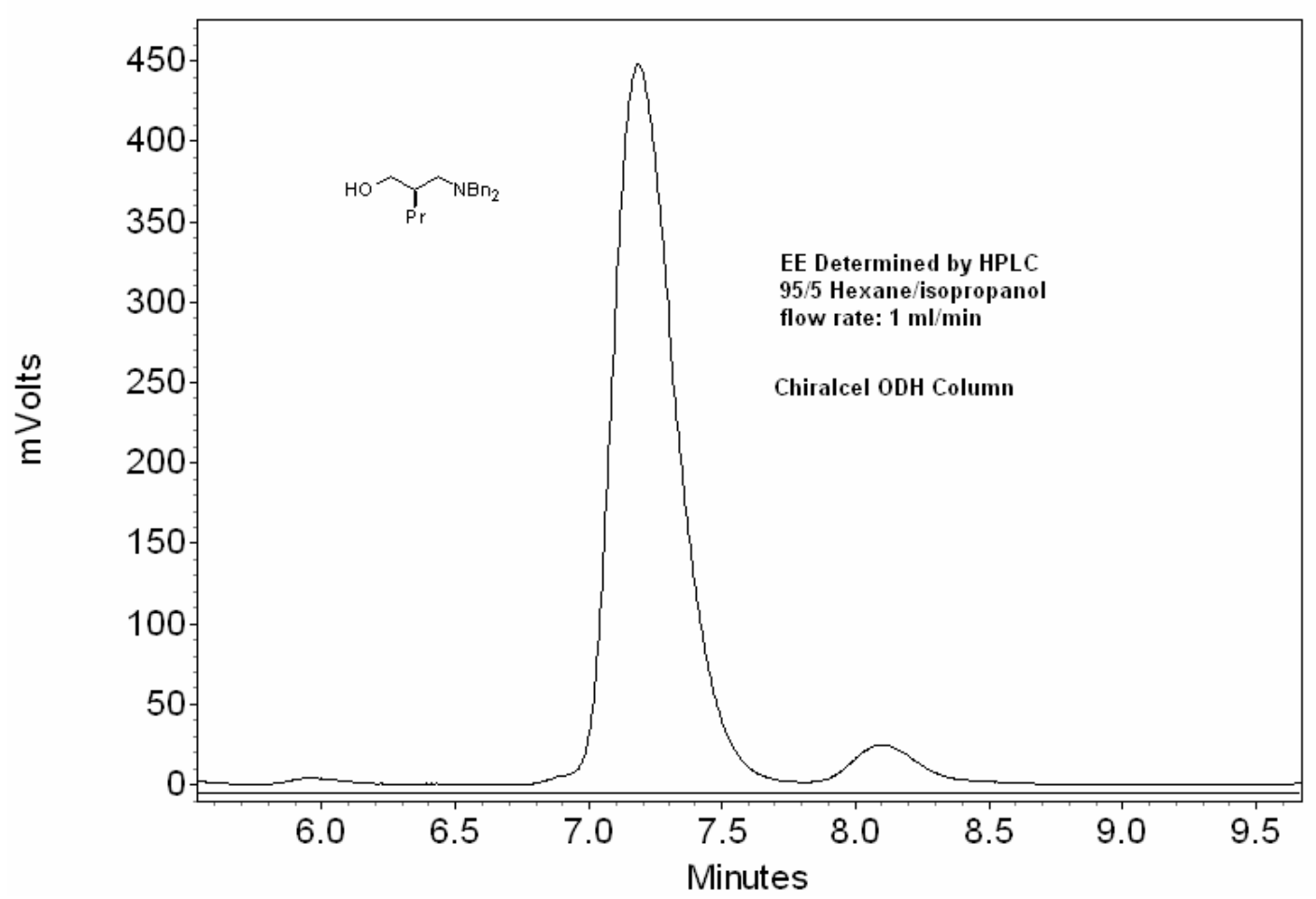


Scheme 2:

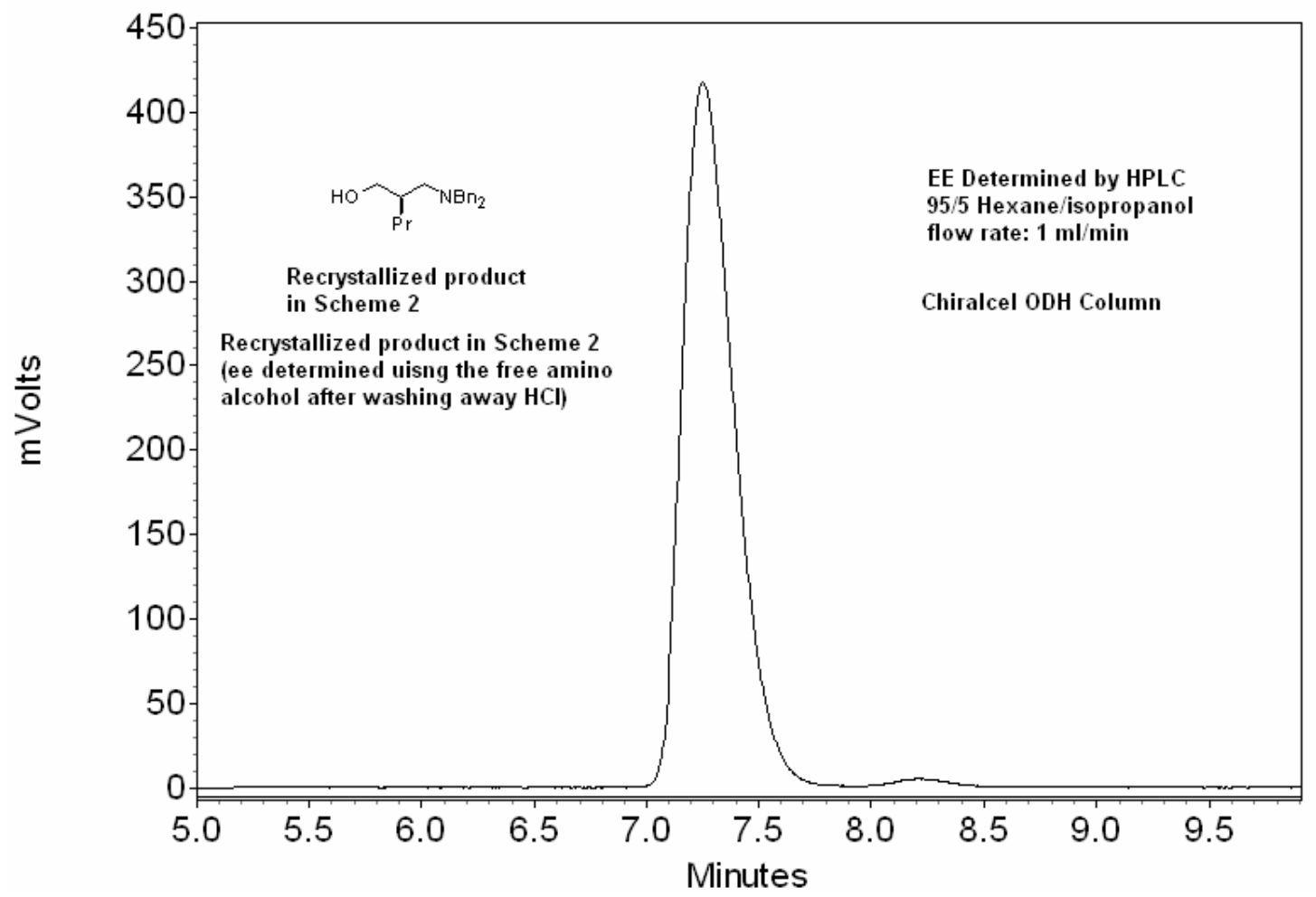

Table 2, entry 3 :

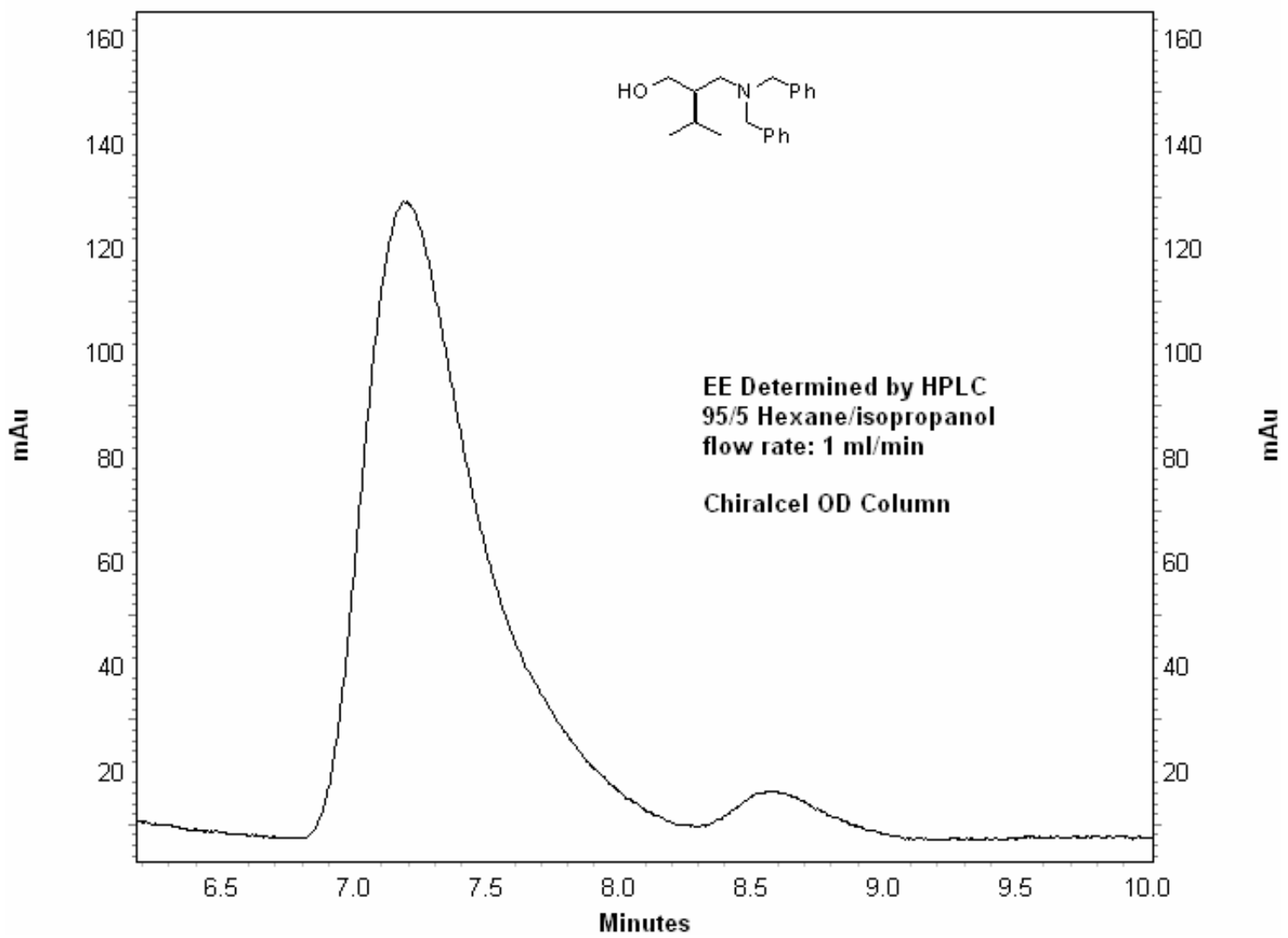


Table 2, entry 4:

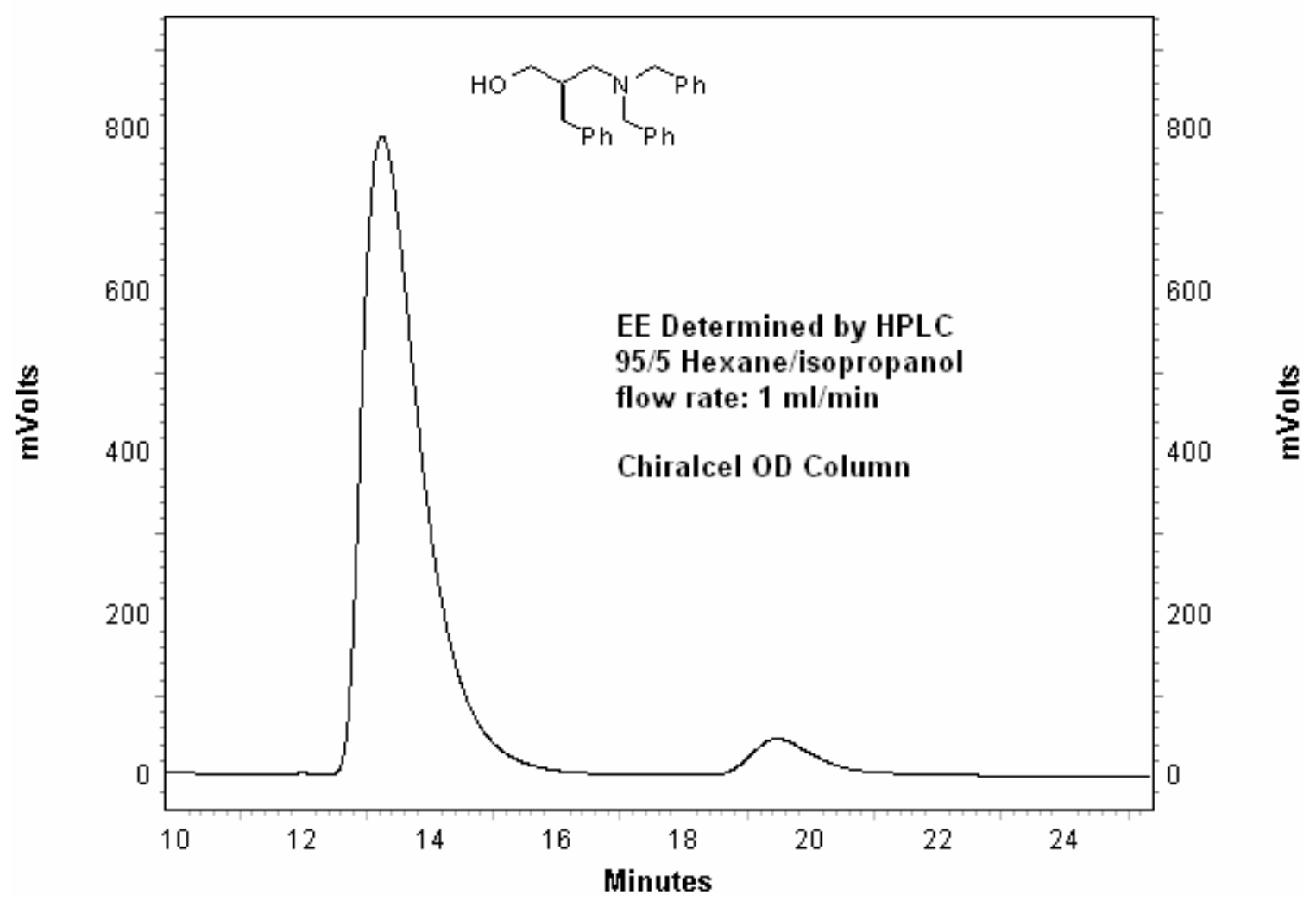

Table 2, entry 5:

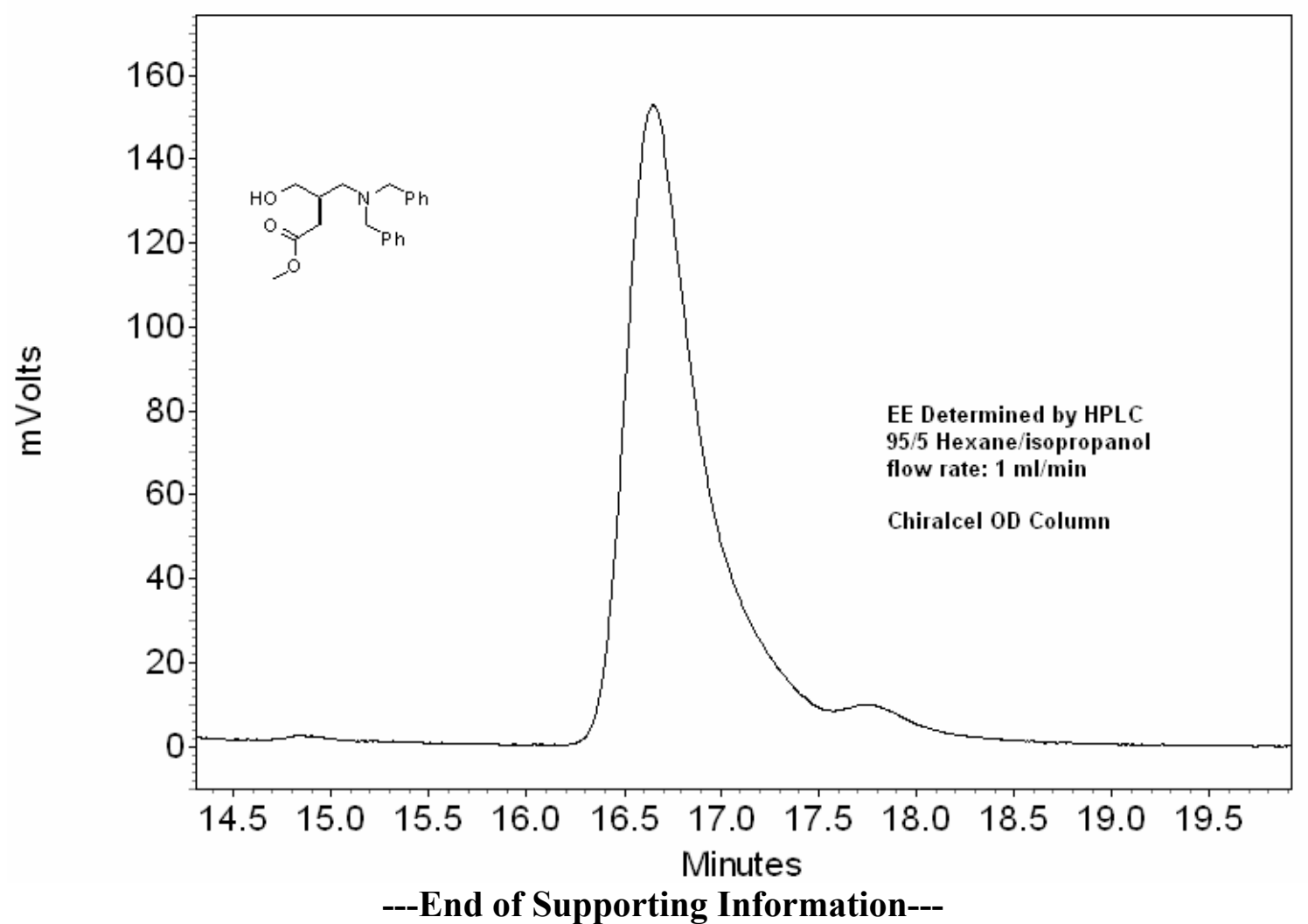

